інтернаціоналізації повинен служити інструментом передачі предметного знання за фахом; а оцінці в інтегрованому курсі повинні піддаватися як знання іноземної мови, так і знання предметної дисципліни. Все це має на увазі активна взаємодія лінгвістичних i предметних кафедр.

В результаті проходження подібного курсу викладач іноземних мов немовного вузу повинен наблизитися до вирішення основного завдання інтегрованого навчання у вузі- розвинути у майбутнього фахівця продуктивні навички ефективного усного та письмового професійноорієнтованого спілкування, підготувати його до двосторонньої ефективної участі в професійному і / або академічному дискурсі в умовах полікультурного світу і тим самим відкрити для нього можливості розвитку міжнародної кар'єри.

\title{
Література:
}

1. Knight J. Five truths about internationalization. International Higher Education // Boston College Magazine. Fall 2012. № 69. URL: www.bc.edu/cihe

2. Graddol D. English Next (2006). British Council. URL: http://www.britishcouncil.org/learning-research-english-next.pdf

DOI https://doi.org/10.30525/978-9934-588-90-7-89

\section{LINGUISTIC AND INTERCULTURAL COMMUNICATION COMPETENCE OF UKRAINIAN SERVICEMEN}

\author{
Turmys O. V. \\ PhD (Philology), Associate Professor, \\ Associate Professor at the Department of Foreign Languages \\ Odesa Military Academy \\ Odesa, Ukraine
}

Modern circumstances and geopolitical scenarios require from the Ukrainian military personnel not only high-quality professional training for performing professional duties in the ranks of the domestic armed forces, but also represent the strategic challenge of developing linguistic competence and the implementation of cross-cultural communication with representatives of foreign armies and fleets. The problem of proper language training and intercultural communication of the military personnel of the Armed Forces of 
Ukraine becomes especially acute due to the need for high-quality interaction with the English-speaking representatives of the Allied Forces during the Armed Conflict in the East of Ukraine.

According to the Deputy Chief of the General Headquarters of the Armed Forces of Ukraine Serhiy Naev: "From 2020, all servicemen, from a soldier to a general, will gradually learn English in order to understand and use staff documents in practical terms. And also so that they can communicate normally during international military manoeuvres". At the same time, the Linguistic proficiency certification assessed on the basis of the Standardization Agreement (STANAG 6001), which since 2019 is received by all graduates of higher military institutions of Ukraine, is a mandatory professional requirement for those, who are seeking promotion, international positions or higher remuneration.

It is therefore difficult to overestimate the strategic role of English as a language for communication in the military profession. English is de facto the language of interoperability, that is, the shared workplace language in multilingual coalitions, the language of doctrine publications, norms or operational procedures that soldiers need to be able to read and write. English language practice involves participation in meetings, negotiations or social conversations with other soldiers or with the local population, technologymediated communication, which are no longer simply a personal choice but a professional requirement [1].

However, for successful communication, representatives of different language groups need not only to gain good knowledge of a foreign language, but also to accept their interlocutors as carriers of a foreign culture, having their own spiritual inner awarenesses, their own worldview. No wonder that by many scientists it is claimed that culture is the fifth language skill (Tomalin 2008) [11].

According to the processes of globalization and intensive migration, research on intercultural communication has recently become increasingly important. The concept of "intercultural communication" was introduced in the 1950s by the American cultural anthropologist Edward T. Hall [2, p. 10].

In intercultural communication, three main types of intercultural communication are usually distinguished - verbal, non-verbal and paraverbal. it was revealed that with the help of language people transmit no more than $70 \%$ of information to their interlocutors. The rest of the information is transmitted by non-verbal means, which are called non-verbal. Thoughts, feelings, sensations can be expressed not only verbally, but also with the help of non-verbal language, which is a very important part of linguacultural baggage. These are gestures, facial expressions, body movements, pauses, or silences, tempo and timbre of speech. [3, p. 36]. Non-verbal language is an 
equal language of culture, like its other languages. Therefore, non-verbal semiotic systems in a communicative act always closely interact with natural verbal language.

For a communicant, a representative of another culture, it is extremely important, entering a new socio-cultural world, to master all the languages of a culture that is new to him. The study of the means of non-verbal communication is extremely important both for the theory of culture in general, and for the general theory of communication in particular. This is due to the fact that the issues of non-verbal communication are of paramount importance for the speech production activity of different nationalities, especially in the modern world, in which the global integrative processes are taking place at all levels of interaction. Non-verbal means of communication are more often used when the process of communication by means of verbal language is difficult between people. Numerous studies of these processes have shown that every nation has its own, extremely diverse arsenal of non-verbal means of communication. Non-verbal means of communication include: -kinesics (facial expressions, gaze, gestures, posture); - prosody (voice and intonation means); - takeshika (touch); - sensing (sensory perception, manifestation of sensations); - prosemics (spatial structure of communication); - chronology (temporal structure of communication) [5, p. 5-7]. In a situation of contact between representatives of different cultures, overcoming the language barrier is not enough to ensure the effectiveness of communication. To achieve this, it is necessary to overcome the cultural barrier.

Speaking the same language, people cannot always understand each other correctly, and the reason is often precisely the divergence of cultures. That is why the Military English-speakers - users of English as the international language of professional communication - face the challenge of communicating in multilingual and multicultural contexts with the representatives of media, local population, other armies, organizations and institutions [7, p. 16].

This means that in order to deal effectively and appropriately with linguistic and cultural diversity, it is essential to equip the Ukrainian military personnel with both the linguistic competence they need to communicate orally and in writing and the intercultural competence they need to understand and accept diversity and to interact with people of other cultures. [4]. And also, along with the study of a foreign language, it is necessary to foster tolerance to a foreign culture, to conduct psychological trainings to eradicate stereotypical thinking, to expand spiritual baggage - to enrich with knowledge about representatives of other cultures. This will enable successful interaction of military with comrades, sister services, allies, adversaries and non-combatants (civilians, international organizations, non-governmental organizations, etc.). 
The development of cross-cultural competence undoubtedly increases operational success, institutional strength and professional well-being of the Army [6, p. 171-194; 7, p. 18; 8, p. 85-96; 9, p. 125; 10, p. 13-33].

It is a difficult task to teach people to communicate (verbally and in writing): to produce, create, understand foreign speech. This task is complicated with the fact that communication is not just a verbal process. Its effectiveness depends on many factors: the conditions of communication, the rules of etiquette, the knowledge of non-verbal forms of expression, the presence of deep background knowledge, etc. The main answer to the question of solving the urgent problem of teaching the Ukrainian military personnel foreign languages as a means of communication between representatives of different nations and cultures is that languages should be studied in an indissoluble unity with the inner world and culture of those people, who speak these languages. It is necessary not only to teach the person a foreign language, but also to teach him to respect another nation's culture.

\section{References:}

1. Bloch, Joel. "Technology and ESP". In the Handbook of English for Specific Purposes, edited by Brian Paltridge, and Sue Starfield, 385-401. Malden, MA: John Wiley \& Sons, 2013.

2. Chen, Guo. "The Impact of New Media on Intercultural Communication in Global Context." China Media Research 8 (2012): 2, 1-10.

3. Culhane, Elizabeth, Patrice Reid, Loring Crepeau and Daniel McDonald (2012). "Beyond Frontiers: The Critical Role of Cross-cultural Competence in the Military." The Industrial-Organizational Psychologist 50 (2012): 30-37.

4. Goh, Christine. "ESP and Listening." In the Handbook of English for Specific Purposes, edited by Brian Paltridge, and Sue Starfield, 55-76. Malden, MA: John Wiley \& Sons, 2013.

5. Kealey, Daniel. "Some Strengths and Weaknesses of 25 Years of Research on Intercultural Communication Competence: Personal Reflections." International Journal of Intercultural Relations 48 (2015): 14-16. Ladegaard, Hans, and Christopher Jenks. "Language and Intercultural Communication in the Workplace: Critical Approaches to Theory and Practice." Language and Intercultural Communication 15 (2015): 1, 1-12.

6. Lario de Oñate, Carmen and María Vázquez Amador. "The Intercultural Component in Business English textbooks." Ibérica, The Journal of the European Association of Languages for Specific Purposes 26 (2013): 171-194. 
7. Lieberman, Devorah, and Glenn Gamst. "Intercultural Communication Competence Revisited: Linking the Intercultural and Multicultural Fields." International Journal of Intercultural Relations 48 (2015): 17-19.

8. Mackenzie, Lauren. "Strategic Enablers: How Intercultural Communication Skills Advance Micro-Level International Security." The Journal of Culture, Language and International Security 1 (2014): 1, 85-96.

9. Miller, John, and Jennifer Tucker. "Addressing and Assessing Critical Thinking in Intercultural Contexts: Investigating the Distance Learning Outcomes of Military Leaders." International Journal of Intercultural Relations 48 (2015): 120-136.

10. Orna-Montesinos, Concepción. (2017). The scope of intercultural communication in a military-specific language learning program. Journal of English for Specific and Academic Purposes. 5. 13-33.

11. Tomalin, Barry. "Culture - The Fifth Language Skill." (2008). Available from: http://www.teachingenglish.org.uk/articles/culture-fifthlanguage-skill

DOI https://doi.org/10.30525/978-9934-588-90-7-90

\title{
АУДІОЛІНГВАЛЬНИЙ МЕТОД ПРИ ВИКЛАДАННІ АНГЛІЙСЬКОЇ МОВИ
}

\author{
Харіна А. В. \\ вчитель англійської мови \\ BUKI Company \\ Украӥна
}

Методика викладання іноземних певний час здійснювала акцент на виборі раціональних методів навчання. I ніколи не існувало єдиного найкращого методу для всіх, та і не завжди можливо та доречно було застосовувати одну і ту ж методологію до всіх учнів, які мають різні цілі, середовище та навчальні потреби. Досвідчений фаховий викладач мови завжди застосовує підхід принципової еклектики, приймаючи рішення про найбільш доречні техніки.

Всі методи покликані здійснити позитивний та негативний вплив, але обов'язково мають нести об'єктивну цінність. Протягом тривалого часу методи викладання мови залежали від суспільства, яке задавало тон, мету, зміст та форму навчання іноземної мови. I якраз одним із них був аудіолінгвальний метод. Він був створений Чарльзом Фрізом на основі 